ELORE (ISSN 1456-3010), vol. 20 - 2/2013.

Julkaisija: Suomen Kansantietouden Tutkijain Seura ry.

[http://www.elore.fi/arkisto/2_13/steel.pdf]

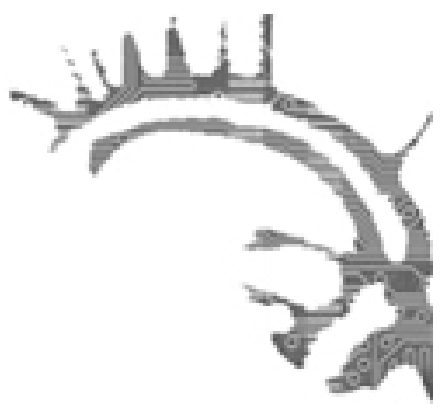

\title{
LECTIO
}

\section{ELOKUVA JA KANSATIEDE}

\author{
Tytti Steel
}

Lectio pracursoria Helsingin yliopistossa 23.8.2013.

Kansatieteellä ja elokuvalla on pitkä yhteinen historia. 1800-luvun kuluessa syntyivät museoiden, näyttelyiden ja kirjallisten julkaisujen etnografiset markkinat, joille elokuvat tulivat mukaan 1890-luvulta lähtien. Etnografinen mielenkiinto kohdistui useimmiten "eksoottisiksi" kuvailtuihin kohteisiin, vieraisiin elämäntapoihin ja alkukantaisina pidettyihin kulttuureihin, kirjoittavat elokuvatutkijat Jari Sedergren ja Ilkka Kippola. Suomalaisella dokumentti- ja kansatieteellisellä elokuvalla on kansainvälisestikin pitkät perinteet. (Sedergren \& Kippola 2009, 250-251.) Tutkijoista ensimmäisenä elokuvakameraan tarttui arkeologi ja kansanelämän tutkija Sakari Pälsi 1910-luvulla. Myös Suomen kansallismuseossa työskennellyt tohtori U. T. Sirelius oli innostunut elokuvan mahdollisuuksista. Hänen mielestään oli "ryhdyttävä toimeen, että kansan tavat, juhlamenot, taiat ja teknilliset menettelytavat tulisivat ikuistetuiksi filmikankaalle". (Sirelius 1921, 244.) Sirelius johti Kalevalaseuran Suojärvelle suuntautunutta kuvausretkeä, jonka lopputuloksena sai vuonna 1921 ensi-iltansa elokuva Häiden vietto Karjalan runomailla (Sedergren \& Kippola 2009, 261). Samana vuonna Sireliuksesta tuli Helsingin yliopiston ensimmäinen kansatieteen professori (Lehtonen 2005, 21).

Vuonna 1933 elokuvien verotuskäytäntöjä muutettiin siten, että lyhyiden dokumenttielokuvien tuotanto maassamme kiihtyi. Useat filmiyhtiöt, erityisesti Aho \& Soldan, kuvasivat arkista elämää ja työntekoa. (Sedergren \& Kippola 2009, 265.) Vuonna 1936 
perustettu Kansatieteellinen Filmi Osakeyhtiö tuotti kuuden toimintavuotensa aikana nelisenkymmentä elokuvaa. Hilkka Vallisaaren mukaan 1930-luvun elokuvatuotanto oli osa laajempaa perinteen keruutyötä, jonka tavoitteena oli ennen muuta maaseudun katoamassa olevien kulttuuripiirteiden "pelastaminen" dokumentoimalla. Elokuvaamisen lisäksi tutkijat valokuvasivat, haastattelivat ja havainnoivat dokumentoinnin kohdetta. (Vallisaari 1984.)

Heinänteko, kaskinauriit, kansantanhut ja tervanpoltto ovat kuvaavia esimerkkejä Kansatieteellisen Filmin elokuvien aiheiden kirjosta. Satamatyöläisten tai merimiesten kaltaiset kaupunkilaiset kansalaiset eivät dokumentoinnin kohteina juuri olleet. Kaupunkilaisten ilmeisesti ajateltiin olevan elokuvien yleisöä, sillä Kansatieteellisessä Filmissä vaikuttaneet pitivät elokuvaa paitsi dokumentoinnin välineenä, myös tärkeänä kansanvalistuksen keinona. (Vallisaari 1984.)

Väitöskirjassani olen käyttänyt lähdeaineistona sekä haastatteluja että elokuvia. Vaikka tutkimusaiheeni ei esiinny Kansatieteellisen Filmin elokuvissa, kuvattiin satamia uutisfilmeissä ja dokumenteissa, jotka kertoivat kaupasta, teollisuudesta sekä merenkulusta. Ajallisesti työni fokus on pitkässä 1950-luvussa, joka ulottuu toisen maailmansodan lopulta 1960-luvulle. Aikakauden dokumenttielokuvissa satama esitetään useimmiten osana kansainvälisen kaupan ketjua, paikkana jossa tuontitavara puretaan laivasta ja vientituotteet lastataan. Elokuvakamera on tallentanut muun muassa voin ja kananmunien lastausta, naudanliha- sekä viljalastin purkamista, puutavaran ja paperin lastausta tai uutiskatsauksen sisältökuvauksen mukaan yleisemmin "erilaisten tuotteiden lastaamista ja purkamista". Erityisesti ammattiyhdistysliikkeen tuottamissa elokuvissa näkyy pyrkimys satamatyön arvon nostamiseen työntekijöiden kunnollisuutta korostamalla. Ahtaajan työn monipuolisuutta ja mielenkiintoisuutta kehutaan. Työn monipuolisuus ja mielenkiintoisuus sidotaan sataman merkitykseen kansantaloudelle. Lyhyiden dokumenttien perussanoma on muistuttaa, että sataman kautta Suomeen tuodaan teollistuneelle yhteiskunnallemme välttämättömiä raaka-aineita ja tuotteita. (Steel 2013, 204-211.)

Yksi edellä mainitun Kansatieteellisen Filmin keskeisistä toimijoista, sittemmin sosiologian professorina toiminut monipuolinen kulttuurivaikuttaja Esko Aaltonen kirjoitti vuonna 1936 seuraavasti: "Filmikamera on monissa suhteissa terävämpi, luotettavampi ja kertovampi kuin ihmissilmä. Se saattaa sopivasti käytettynä paljastaa liikkeitä, joille silmä on sokea, ja kertoa tapahtumista lahjomattomuudella, joka ei yleensä ole elävälle havainnoijalle ominaista." (Sedergren \& Kippola 2009, 270.) Aaltosen ajattelutapa edustaa yleistä käsitystä, jonka mukaan kamera kuvaa maailmaa välittömästi ja suoraan, objektiivisesti ilman ihmisen vaikutusta (Easthope 1998, 51; Vonderau 1999, 16). Elokuvassa näemme ihmiset ja toiminnan sellaisina kuin ne olivat. Silti dokumenttielokuvakin välittää ainoastaan rajatun näkökulman kohteeseensa (esim. Mäkelä \& Oittinen 1993, 38). Elokuva on aina representaatio, kuvaus tai esitys. Se on merkityksien antamista ja puuttumista todellisuuteen, vaikka lopputulos tuntuisikin todenmukaiselta. (Easthope 1998 , 54.) Elokuvantekijän mahdollisuuksia rajaa paitsi mielikuvitus, myös tekniikka, se minkälaisia kameroita, valoja ja muita välineitä hän pääsee käyttämään (Plantinga 1997, 147). 
Suomi Filmi Oy:n ja Suomen kuljetustyöväen liiton tuottama Valtasuoni sykkii vuodelta 1948 alkaa korostamalla juuri tämän elokuvan antamaa totuudenmukaista kuvaa seuraavasti:

\begin{abstract}
Aikakautemme kiivas rytmi on vetänyt yksityisenkin ihmisen mukaansa. Se on tehnyt hänet levottomaksi. Kiivaan rytmin lyhyinä taukoina ihminen etsii unohdusta ja tässä mielessä täyttyvät tuhannet elokuvateatterit. Elokuvat yleensä kertovat meille sankareista, joiden mielikuvitukselliset teot johtavat luonnottomiinkin voittoihin. Heidän kauttaan meidät tuuditetaan todellisuuttaan turruttavaan uneen. Tässä elokuvassa elämä sykkii kiihkeänä, mutta se ei ole valhetarinaa, vaan jokapäiväisen elämän arkea. Sankareina ovat työ ja sen tekijät, jotka esitämme sellaisina kuin he ovat.
\end{abstract}

Selostaja vakuuttaa elokuvan kertovan jokapäiväiseen elämäämme liittyvästä "monivivahteisesta, raskaan raadannan ja uuvuttavan uurastuksen verhoamasta" kuljetustyöstä. Kertomuksen kaari kulkee lakonuhasta lakkoon ja sen päättymiseen työntekijöiden voittoon, palkankorotuksiin. (Steel 2013, 207-209.)

Dokumenttielokuvien tekijät korostavat samoja asioita kuin fiktiivisten elokuvien käsikirjoittajat ja ohjaajat: hyvässä dokumentissa on tarina ja kiinnostava päähenkilö, johon katsoja voi samastua. Fiktiivisen elokuvan draamallista rakennetta käytetään apuna, jotta elokuva saadaan koskettamaan katsojaa ja herättämään hänessä tunteita. Dokumentaristi Jouko Aaltosen $(2003,152)$ mukaan dokumenttielokuvan erottaa fiktiosta vain tapahtumien — tai ainakin henkilöiden — ja tapahtumapaikkojen todellisuus. Dokumentaristit eivät ajattele tuottavansa todellisuutta uudelleen, vaan enemmänkin haluavat kommentoida ja väittää jotakin todellisuudesta.

Dokumenttielokuvien ja haastatteluaineiston intentioita voi pitää samansuuntaisina: molemmat pyrkivät kertomaan asioista totuudenmukaisesti, mutta välittävät subjektiivisia näkemyksiä. Haastattelupuhe liikkuu kahdella aikatasolla, muisteltavassa menneessä ja haastattelujen nykyisyydessä. Etnologi Pirjo Korkiakangas on kirjoittanut, että kahden aikatason vuoropuhelu sävyttyy usein retoriseksi, jolloin muistelija haluaa esittää asiat tietyllä tavalla nykyisyydestä käsin. Korkiakankaan mukaan muisteltaessa ei niinkään kerrota todellisuudesta, vaan tuotetaan koetun todellisuuden tulkintoja. (Korkiakangas 2006, 133.) Historioitsija Alessandro Portelli on todennut, että muistitieto kertoo enemmän tapahtumien merkityksistä kuin itsessään historiallisista tapahtumista. Tämä ei vähennä muistitiedon arvoa lähdeaineistona, sillä haastattelujen kautta voidaan saada tietoa tapahtumista, joita ei ole muuten dokumentoitu tai saada uusi näkökulma jo tunnettuun aiheeseen. Haastatteluissa tulevat esiin mielikuvitus, symbolit sekä halut ja muut tunteet. Portellin mukaan muistitieto ei ole objektiivista, mutta hän huomauttaa, etteivät kirjallisetkaan lähteet ole syntyneet ilman tulkintaa ja rajausta - ja nekin pohjautuvat usein suullisiin kertomuksiin. Ei ole "väärää" muistitietoa, sillä se mikä kullekin subjektiivisesti on totta, on merkittävää, vaikka se ei olisikaan faktuaalisesti totta. Tutkijan tulee ymmärtää muistitiedon luonne ja pyrkiä käyttämään sitä hyödyksi. Muistitieto kertoo siitä mitä ihmiset tekivät, mutta erityisesti siitä, mitä he halusivat tehdä, mitä he uskoivat tekevänsä, ja mitä he ajattelevat tehneensä. (Portelli 2008, 35-38.) 
Dokumenttielokuvissa arjen tapahtumia dramatisoidaan ja järjestellään ymmärrettävästi eteneväksi tarinaksi. Tapahtumat kronologisessa järjestyksessä esittävä dokumenttielokuva on rakenteeltaan lähellä "klassisia" Hollywood-elokuvia tai ainakin saanut niistä vaikutteita (Plantinga 1997, 124 ja 133). Satamadokumenteissa tarinan kaari rakennetaan usein laivan saapumisen ja lähdön dramatiikalle. Myös eurooppalainen toisen maailmansodan jälkeen versonut taide-elokuva on vaikuttanut dokumenttielokuvan tyyliin (Plantinga 1997, 139; Monaco 2000, 313-318). Oman aineistoni dokumenteista taideelokuvan vaikutteet näkyvät erityisesti dokumenteissa Valtasuoni sykkii, josta äskeinen lainaus, sekä siitä lyhennetyssä ja uudistetussa versiossa nimeltään Satama. Valtasuoni sykkii -elokuvassa vaihtelevat selkeästi ammattiyhdistysliikkeen agendalla oleva faktapitoinen selostus ja kuvasto sekä seesteisemmät, esimerkiksi odottavien työntekijöiden kasvoissa ja ryhmäkuvissa viipyilevät jaksot, joissa taide-elokuvan vaikutus on ilmeinen.

Myös fiktiivinen elokuva voi paikoin toimia dokumentin tavoin. Esimerkiksi Mika Kaurismäen elokuva Arvottomat vuodelta 1982 alkaa ilmakuvalla Helsingin Länsisatamasta. Kuvissa näemme sataman laiturit ja varastot, laivat ja nosturit miltei yhtä elävästi kuin jos olisimme itse helikopterissa kuvausryhmän kanssa. Ilmakuva on kuitenkin hyvä esimerkki siitä, miten kameran takana toimivat ihmiset määräävät rajauksen, kuvakulman ja kuvakoon eli tarkastelun mittakaavan. Elokuvantekijä kontrolloi rakentamaansa esitystä aina valitsemalla, järjestämällä, painottamalla ja ottamalla tietyn näkökulman. Elokuvaan tulevaa materiaalia valitaan käytännön syistä sekä retorisessa tarkoituksessa. Myös haastatteluaineisto muodostuu samalla tavoin rajaamalla ja järjestämällä. Haastattelija ohjaa tilannetta kysymyksillään, mutta haastateltava valitsee, mitä asioita kertoo ja mitä jättää kertomatta. Jokaiseen tutkimusprosessiin sisältyy suuri määrä näkökulman valintoja, painotuksia sekä rajauksia.

Katsoja voi pitää täysin fiktiivistä elokuvaa realistisena, dokumentin omaisena kuvauksena todellisuudesta. Esimerkiksi Aki Kaurismäen ohjaamia elokuvia on pidetty suomalaisuuden kuvaajina ja edustajina ulkomailla (Bagh 1992, 349). Elokuvan tekijät pyrkivät todentuntuiseen lopputulokseen siten, että katsojan olisi mahdollista eläytyä elokuvan maailmaan ja sen henkilöhahmojen elämään. Elokuvan katsominen on kokonaisvaltainen elämys, joka vaikuttaa katsojiensa ajattelutapaan ja mielikuviin. Elokuvat ovat läsnä ihmisten arjessa monin tavoin. Niihin voi heijastaa omia tunteita, tuntemuksia ja kokemuksia. Niiden aiheet ja tarinat on tehty siten, että monet voivat kokea ne itselleen läheisiksi. Olemalla läsnä ihmisten arjessa elokuvat ovat myös vaikuttaneet siihen. (Lehtola 2000, 15; Monaco 2000, 33, 396.)

Richard Rieser (2011), joka on tutkinut vammaisuuden esittämistä elokuvissa ja televisiossa, on verrannut liikkuvan kuvan esittämää kuvaa "unimaailmaan", joka ei ole todellinen, mutta jonka kautta ihmiset yhtä kaikki määrittävät itseään. Rieser uskoo, että elokuvilla on suuri vaikutus tunteisiin, käyttäytymismalleihin sekä siihen, miten suhtaudumme ympäröivään maailmaan. Rieser tuo esiin myös käytännön esimerkin elokuvan vaikutuksesta vammaisuutta koskeviin asenteisiin. Disneyn tuottaman Notre Damen kellonsoittaja -elokuvan ilmestymisen jälkeen Britanniassa skolioosia sairastavien etujärjestö raportoi yli sata hyökkäystä, jotka kohdistuivat selkärangan kiertymää sairastavia henkilöitä kohtaan. Hyökkäykset tapahtuivat puoli vuotta elokuvan ensi-illan jälkeen, eikä niitä ollut tapahtunut lainkaan ennen elokuvan ilmestymistä. 
Elokuvien luomilla mielikuvilla on merkitystä. Elokuvatutkija Teresa De Lauretis $(2004,53)$ on väittänyt, että elokuvat vaikuttavat voimakkaasti siihen, miten ihmiset käsittävät itsensä, toisensa ja sosiaaliset suhteet. Myös elokuvatutkija Carl Plantingan mukaan dokumenttielokuvilla on kulttuurissamme suuri valta. Ne neuvottelevat arvoja ja merkityksiä, levittävät paikkansapitävää ja valheellista tietoa, kannustavat ja ohjaavat sosiaaliseen muutokseen sekä luovat merkittäviä kulttuurisia keskusteluja. (Plantinga $1997,85-87,89,191$.) Elävällä kuvalla ja siihen yhdistetyllä äänellä on ainutlaatuinen kyky koskettaa meitä tunteen tasolla (Hietala 1999, 244). Fiktio vaikuttaa toimintaamme ja ajatteluumme jatkuvasti ja osittain selittämättömästi. Esimerkiksi rautatieasemalla mielessämme piilee joukko representaatioita kirjoista, elokuvista, mainoksista ja musiikista. Eron ja jälleennäkemisen hetket ovat piirtyneet mieliin usein tiedostamattomasti. (Ehn \& Löfgren 2007, 43.)

Satamien mainetta 1950-luvulla leimasivat lakot, prostituutio ja salakuljetus. Stereotyyppinen kuva tuon ajan satamatyöntekijästä lienee rehvakas ja viinaanmenevä isokokoinen mies. Ahtaajien huono maine kulminoituu esimerkiksi Alkon vuoden 1951 mainoskampanjassa esiintyvässä vastuuttomassa ja räyhäävässä satamajätkän representaatiossa. Aikakauden näytelmäelokuvissa satamatyöntekijät esitettiin kuitenkin raittiina ja reiluina työmiehinä, jotka ratkoivat ongelmia, eivätkä aiheuttaneet niitä.

Matti Kassilan ohjaamassa elokuvassa Professori Masa ahtaaja Väiski toimii professori Mathias Kaarivaaran elämän mentorina, kun lakkoja tutkiva professori päätyy sattumalta tilapäistöihin satamaan. Edvin Laineen elokuvassa Nokea ja kultaa satamajätkä Jalmari Aaltonen puolestaan adoptoi orvon ja kaltoin kohdellun lapsen. Luettuani ristiin näitä elokuvia, niihin liittyvää media-aineistoa sekä haastatteluaineistoani, tulkitsen näytelmäelokuvien satamatyöntekijärepresentaatiot vastakuvaksi huonomaineiselle satamajätkän kuvalle. Näytelmäelokuvien siloteltu ja positiivinen kuva on yhteydessä työntekijöiden kokemukseen stigmasta ja syrjityksi tulemisesta. Kassilan Professori Masan kohdalla osallistuminen yhteiskunnalliseen keskusteluun on ilmeistä. Elokuvaa tehtäessä pyyhki Suomea lakkoaalto, joka kärjistyi Kemissä väkivaltaiseksi mellakaksi, jossa kuoli kaksi lakkolaista. (Steel 2013, 214-220.)

Fiktiiviset elokuvat näyttävät aiheen käsittelytavan kautta heijastavan oman aikansa todellisuutta, mutta ovat myös uusien merkityksien luojia. Fiktio voi vaikuttaa monella tavalla aistimaamme ympäristöön. Se voi luoda uusia merkityksiä, vahvistaa tai muuttaa ennakkokäsityksiämme. Kun aistimamme todellisuuden ja fiktion rajat hämärtyvät, syntyy uusia todellisuuden representaatioita. (Ehn \& Löfgren 2007, 181; Tani 1995, 56,88 .) Joskus katsojan on vaikeaa tai mahdotonta tietää, mikä elokuvassa perustuu historian tutkimukseen ja mikä on tekijöiden spekulaatiota (Plantinga 1997, 19, 23). Katsoja voi pitää fiktiota todellisuuden kuvaajana, mutta tekijät voivat vedota taiteilijan vapauteen tarinan maailmaa luodessaan. Esimerkiksi vuodelta 2004 olevan Pekka Mandartin ohjaaman Keisarikunta -elokuvan alkutekstien taustalle on valittu valokuvia Kotkan sataman historiasta ainakin Kymenlaakson museon kokoelmista. Arkistokuvat mustakylkisine laivoineen ja huivipäisine naisahtaajineen virittävät katsojan ajatukset 1950-luvun elettyyn ja koettuun arkeen, vaikka elokuvan tarina on musikaalimainen satu. Ohjaaja itse on todennut, että Keisarikunnassa on paljon keksittyä, mutta elokuva on silti totta, koska se on täynnä tunnetta. (Steel 2013, 41-45.) 
Tutkimuksen kannalta ei ole mielekästä tarkastella fiktiivisiä elokuvia kysyen, mikä niissä on totta tai tarua. Näytelmäelokuvien on tarkoitus viihdyttää ja herättää ajatuksia, kertoa kiinnostavia tarinoita. Elokuvatutkija Richard Dyer (1985) on kirjoittanut viihteestä, erityisesti musikaaleista, utopioiden välittäjinä. Viihde-elokuvien utopia on pakopaikka, jossa asiat ovat paremmin kuin katsojan omassa elämässä. Dyerin mukaan elokuvien utopiat eivät ole klassisia utopioita siinä mielessä, että ne kertoisivat siitä miten parempi maailma olisi järjestetty. Sen sijaan elokuvat kertovat siitä, miltä utopiassa tuntuisi elää. Keisarikunta-elokuvaan liittyvässä lehdistöaineistossa korostuu nostalginen näkemys 1950-luvun Kotkasta ja sen satamasta. Dyerin utopia-ajatusta voisi soveltaa Keisarikuntaan siten, että se on unelma suvaitsevaisesta ja kansainvälisestä Suomesta. Elokuvaan liittyvässä media-aineistossa rakentuva kuva, johon kuuluvat arkisten ylirajaisten kohtaamisten positiivisuus, kaupungin vireys ja ihmisten hyväntuulisuus, neuvottelee uusiksi jäyhää Suomi-kuvaa. Tulkitsen elokuvan ja siihen liittyvän ylirajaisuuspuheen sulkeutuneen, talonpoikaisen ja pysähtyneen Suomi-kuvan kiistämiseksi.

Elokuva tarjoaa kansatieteelliselle tutkimukselle paljon mahdollisuuksia, joita voitaisiin hyödyntää nykyistä enemmän. Elokuvien käyttö lähteenä on ollut yllättävän vähäistä, kun ottaa huomioon alkuaikojen innostuksen ja Kansatieteellisen Filmin menestyksen. Elokuvan multimodaalisuus - liikkuvan kuvan, äänen ja erilaisten tehosteiden yhdistelmä - tekee siitä työlään analysoitavan ja vaikeasti siteerattavan.

Digitekniikka ja internet ovat kuitenkin mullistaneet elokuvan tekemisen prosesseja ja elokuvan katsomisen tapoja. Muun muassa antropologi George Marcus on peräänkuuluttanut uudenlaista tapaa tehdä etnografista tutkimusta. Marcus on toivonut, että tutkijat tekisivät yhteistyötä taiteilijoiden sekä tutkittavien ihmisten kanssa. Taiteilijoista Marcus nostaa esimerkiksi teatterilavastajan, jonka silmä kartoittaa ja tulkitsee arkiympäristöämme samaan tapaan kuin tutkijan etnologinen katse. (Calzadilla \& Marcus 2006, 97.) Myös elokuva tarjoaa hyviä mahdollisuuksia tutkijoiden ja taiteilijoiden yhteistyöhön. Näin toimivat itse asiassa jo Kansatieteellisen Filmin aktiivit.

Tutkijoiden kiinnostuksen kohteet ovat Kansatieteellisen Filmin ajoista muuttuneet. Professori Hanna Snellman on todennut, että objektiivisen totuuden etsimisen sijaan kansatieteilijät etsivät subjektiivisia totuuksia. Lähteiden epätarkkuus tai epämääräisyys eivät enää häiritse tutkijaa, vaan ovat kiinnostuksen kohteena. (Snellman 2005, 20.) Yhtä perustavanlaatuinen muutos on käynnissä juuri nyt. Tutkijat lienevät Marcusin kanssa yhtä mieltä siitä, että tutkimuksen kohteena olevat ihmiset olisi nykyistä useammin ja nykyistä tiiviimmin otettava mukaan koko tutkimusprosessiin. Elokuvan multimodaalisuus on myös sen vahvuus: liikkuvan kuvan ja äänen yhdistelmä voi olla tutkittavalle helpommin lähestyttävä ja kiinnostavampi tulkittava kuin paperille sanoiksi pakotettu akateeminen teksti. Elokuva voi olla hyvä väline tutkimusasetelmassa, jossa tutkimuksen kohde on myös itse tutkija ja vastaavasti tutkija on tutkittavan analysoivan ja reflektoivan katseen kohteena.

Näen kansatieteen ja elokuvan yhteisen historian jatkuvan kiinnostavana myös tulevaisuudessa. 
Tytti Steel: Elokuva ja kansatiede

\section{KirJallisuUs}

AALTONEN,JOUKO 2003: Käsikirjoittajan työkalut. Audiovisuaalisen käsikirjoituksen tekijän opas. Helsinki: SKS.

BAGH, PETER VON 1992: Suomalaisen elokuvan kultainen kirja. Helsinki: Otava ja Suomen elokuva-arkisto.

CALZADILLA, FERNANDO \& MARCUS, GEORGE E. 2006: Artists in the Field: Between Art and Anthropology. - Schneider, Arnd \& Wright, Christopher (eds), Contemporary Art and Anthropology. Oxford: Berg.

DE LAURETIS, TERESA 2004: Itsepäinen vietti. Kirjoituksia sukupuolesta, elokuvasta ja seksuaalisuudesta. Tampere: Vastapaino.

DYER, RICHARD 1985: Entertainment and Utopia. -Nichols, Bill (ed.) Movies and Methods. Volume II. Berkeley: University of California Press.

EASTHOPE, ANTHONY 1998: Classic film theory and semiotics. - Hill, John \& Church Gibson, Pamela (eds) The Oxford Guide to Film Studies. Oxford: Oxford University Press.

HIETALA, VEIJO 1999: Tunne ja elämys audiovisuaalisessa kulttuurissa. —Näre, Sari (toim.) Tunteiden sosiologiaa I. Elämyksiä ja läheisyyttä. Helsinki: SKS.

KORKIAKANGAS, PIRJO 2006: Etnologisia näkökulmia muistiin ja muisteluun. -Fingerroos, Outi et al. (toim.), Muistitietotutkimus. Metodologisia kysymyksiä. Helsinki: SKS.

LEHTOLA, JORMA 2000: Lailasta Lailaan. Tarinoita elokuvien lappalaisista. Inari: Kustannus-Puntsi.

LEHTONEN, JUHANI U. E. 2005: Kansatieteen tutkimushistoria. —Korkiakangas, Pirjo Olsson, Pia \& Ruotsala, Helena (toim.), Polkuja etnologian menetelmiin. Helsinki: Ethnos ry.

MONACO, JAMES 2000: How to Read a Film. The World of Movies, Media and Multimedia: Language, History, Theory. 3. p. New York: Oxford University Press.

PLANTINGA, CARL R. 1997: Rhetoric and representation in nonfiction film. Cambridge: Cambridge University Press.

PORTELLI, ALESSANDRO 2008: What Makes Oral History Different. - Perks, Robert \& Thomson, Alistair (eds), The Oral History Reader. Second Edition. London: Routledge.

RIESER, RICHARD 2011: Mustat lasit. Vammaisuus valkokankaalla ja televisiossa. Helsinki: Into.

SEDERGREN, JARI \& KIPPOLA, ILKKA 2009: Dokumentin ytimessä. Suomalaisen dokumentti-ja lyhytelokuvan historia 1904-1944. Helsinki: SKS.

SIRELIUS, U. T. 1921: Suojärven filmiretki. - Kalevalaseuran vuosikirja 1. Porvoo: WSOY.

SNELLMAN, HANNA 2005: The Road Taken. Narratives from Lapland. Inari: Kustannus-Puntsi.

VALLISAARI, HILKKA 1984: Kansatieteellisen elokuvan alkuvaiheet Suomessa. Helsingin yliopiston kansatieteen laitoksen tutkimuksia 11. Helsinki: Helsingin yliopisto. 
VONDERAU, PATRICK 1999: Historiography and Film: A Dangerous Liaison? Film as History / History as Film. Arbeitspapiere - Gemeinschaften Volume 21. Berlin: Humbolt-Univärsität.

STEEL, TYTTI 2013: Risteäviä eroja sataman arjessa. Kansatieteellisiä tutkimuksia Helsingin yliopistosta 17. Helsinki: Helsingin yliopisto. http://urn.fil URN:ISBN:ISBN 978-952-10-9013-4

Tytti Steel väitteli Helsingin yliopiston kansatieteen oppiaineessa. Steel työskentelee Helsingin yliopistossa merihistorian ja museologian amanuenssina. Hän on työskennellyt pitkään myös Suomen merimuseossa. 